\title{
Some Social Characteristics of CEGEP Graduates'
}

\author{
ANN B. DENIS*
}

\begin{abstract}
As part of the "Quiet Revolution" in Quebec in the 1960's, changes have occurred both in the educational structures and in the population undertaking post-secondary studies. $A$ new post-secondary institution, the CEGEP, has been introduced. As a preliminary step in the study of accessibility to the CEGEP, the social class, ethnicity and sex of its graduates are related to their course of study at CEGEP and their subsequent work or educational activities. There were no clear-cut patterns of ethnic or social class differences in choice of specialisation. Although field of specialisation remained strongly sex-linked, women constituted a significant proportion of the graduates. Social classes continued to be distributed inequitably in the student population, although the disparities varied with ethnicity, being least in the case of those whose origins were neither English nor French. The pre-university programme, as intended, was being treated as part of a cycle of post-secondary education, and suitable employment for graduates of the terminal, vocational programmes was not a problem.
\end{abstract}

\section{Introduction}

In his study of Who Doesn't Get to University - and Why (1970), Robert Pike considered the impact of both financial and non-financial factors on accessibility to Canadian postsecondary education in the 1950's and 1960's. This wide ranging examination of available data highlighted participation differentials by sex, social class, and community of residence which were similar to those noted in American (Jencks and Riesman, 1968; Sewell 1971) and British (Halsey et. al., 1961, Little and Westergaard, 1964) studies. The gaps in available data were also notable, particularly for the period since the mid 1960's, a period of considerable change in educational philosophies and structures for some provinces, notably Quebec. In such instances, Pike observed:

\footnotetext{
${ }^{1}$ This is a revised version of a paper presented at the annual meeting of Canadian Sociology and Anthropology Association in Kingston. 1973. The research on which this paper is based was made possible by a grant from the Canada Council. The author acknowledges with thanks the comments of John Lipkin and Robert Pike on earlier drafts of this paper.
}

*Associate Professor, Department of Sociology, University of Ottawa. 
the claim that there has been no narrowing of the accessibility gap for lower-workingclass children (i.e. those from semi-skilled and unskilled manual backgrounds) needs to be subjected to critical evaluation. It would certainly be surprising to learn that Quebec's "quiet educational revolution", with its emphasis on measures designed to promote greater equality of educational opportunity amongst children of the province, had not led to a relative improvement in the university attendance chances of lower-workingclass children vis à vis children from other social class backgrounds (1970:63).

The class factor also has ethno-linguistic dimensions in Quebec: the English are overrepresented in the middle and upper classes, and, as one could predict from this, a larger proportion of English than of French have obtained post-secondary education. Moreover, French education has been more elitist than the English education in the province and its acquisition has involved greater costs in time and money. Furthermore, there have been value differences between the groups, with the traditional French value system affording greater prestige to the liberal professions, to the detriment of training for administrative, scientific and technological occupations (Government of Quebec, 1963; Rioux and Martin, 1964; Denis, 1975).

The "quiet educational revolution" to which Pike refers was part of the more general "Quiet Revolution" which occurred in Quebec during the 1960's under the provincial government of Jean Lesage. During this period trends towards secularisation, urbanisation and industrialisation crystallised, and a new bureaucratic and technocratic middle class emerged among the Quebec francophones (Guindon, 1964). With the expansion of the secondary and tertiary sectors of the economy new categories of occupations requiring highly trained manpower emerged. The existing francophone education structures, oriented primarily to the training of a small elite and already under criticism since the 1950's (Frère Untel, 1960), were deemed incapable of providing the widespread education required. Moreover, as the ethnic division of labour in the province (Hall, 1971) was replaced by competition between anglophones and francophones for administrative and technological positions, it became evident that here the francophones' classical educational system put them at a disadvantage. Their training took longer to complete and prepared them mainly in the humanities rather than in commercial, scientific or technological subjects.

Because of its relation to the development of an industrialised, technological society, education was defined as a priority by the Lesage government and a Royal Commission (the Parent Commission) was established in 1961 to recommand educational reforms. The Commission's Report (Government of Quebec, 1963, Vol. 1, Ch. 4) emphasised the concept of education as a right for all who might benefit from it, both to prepare the individual for life in society and as a means for both men and women to acquire job-related skills. Humanistic, scientific and technological components all figure in such a concept of education. Following from the Report a uniform educational system has been instituted for all, aimed at minimising the effects of sex, social class and ethnicity on the educational alternatives available. Not only was this intended to increase equality of educational opportunity, but also to increase overall participation in education.

Concretely, at the post-secondary level the changes have included the establishment since 1967-8 of Colleges of General and Professional Education (CEGEPs) throughout the province. By 1971 there were 37, 4 of them anglophone. They are tuition-free institutions, 
which are entered after completion of eleven to twelve years ${ }^{1}$ of primary and secondary school. As comprehensive institutions they are unique in that all students pursuing their education beyond the secondary level must attend them, either in the two year general (pre-university) programme, or in the three year vocational (terminal) one which trains technologists and technicians. Offering both types of programme in the same institution and including a common core of language and philosophy/humanities ${ }^{2}$ in both were measures intended to increase the attractiveness of administration, science and technology for the French students.

\section{Review of the Literature}

Since the establishment of the CEGEPs their students have been studied from a variety of perspectives. The Ministry of Education, le Centre d'animation, de développement et de recherche en éducation (C.A.D.R.E.), a research organisation associated with it, and individual CEGEP's have studied the student population and CEGEP graduates quite extensively (for example: Gouvernement du Québec, 1972; C.A.D.R.E., 1973; CEGEP de Sherbrooke, 1971). These studies have focussed largely on the students' numbers, subject choices, subsequent job or study experiences and attitudes towards instruction, counselling, and extracurricular activities within CEGEPs. Little attempt has been made in these studies to relate these variables to socio-demographic characteristics of the students, so that it is rarely possible to compare participation in post-secondary education or attitudes to it by social class, ethnic group or sex from these "official" data. They are however useful as a statistical base for examining the CEGEP system as a whole over time. One notes, among other things, the very rapid increases in enrolment during the first years of the CEGEP's existence; the shift in sex ratio as additional programmes, notably nursing, opened up in the vocational sector; and a shift over time towards the vocational sector, so that students are now approximately equally divided between the two, in contrast with the overwhelming majority in the pre-university programme initially.

Academic researchers (for example Denis and Lipkin, 1972; Escande, 1973; Ouellet et. al., 1972) have examined the social composition of selected CEGEPs, in relation to such variables as subject choice, job aspirations and expectations and satisfaction with the CEGEP. Baby et. al.'s project (1969) also incorporated comparisons with the population in nearby classical colleges which were continuing to offer fee-paying alternative programmes. Most of these studies have considered students currently in the institution, often in their first year there. As will be outlined more fully in later sections of this article, the CEGEP's population is largely middle class in origin, although in metropolitan centres this varies

${ }^{1}$ Another recommendation of the Parent Commission was that it should take eleven years to complete secondary school. In the French system the transition from a twelve to an eleven year cycle is still in process.

${ }^{2}$ Subsumed under the label "philosophy" in the francophone CEGEP's is a compulsory sequence of courses "initiation au projet philosophique," "les visions du monde," "la condition humaine," "la conduite humaine." The parallel sequence in anglophone CEGEP's includes "Man and his world views," "Man and society," "Man and the arts," "Man and his search for knowledge and its application." The use of two distinct labels and the difference in emphases in the two sequences is indicative of the differences in presuppositions of anglophone and francophone educators, and the compromises that were necessary to establish a common programme for all. 
somewhat according to the institution's location and antecedants: institutions in predominantly working class areas have a larger working class population, while those which developed from previously prestigious classical colleges seem to have continued to attract an elite population from throughout the city. Choice of specialisation seems strongly sex linked with girls favouring education, nursing and arts and avoiding pure or applied science and commerce.

\section{Theoretical framework}

As another step in the study of accessibility to the CEGEP this article presents data on selected social characteristics of graduates of two CEGEPs in relation to their choice of specialisation and subsequent work or educational experience. By considering graduates it is possible to examine how in its earliest years this new institution integrated with the existing work and educational structures, and whether, for pre-university students, the fact of having completed two years beyond high school tuition-free affected the likelihood of their embarking on university studies. By way of comparison, Pike has estimated that between 70 and $86 \%$ of those eligible for university entrance in four provinces in 1966 did in fact enrol (1970: 25-26). From the more detailed CEGEP data it will also be possible to compare the background characteristics of eligible students who did and did not pursue their studies at university.

This may be of particular interest in the case of the girls. As Pike (and others) have noted, at the secondary level girls' academic performance and their retention rate in the school system equal or exceed those of boys. However, girls have been under-represented in universities, choosing instead to enrol in shorter post-secondary programmes or to begin work immediately after graduating from high school. Sociologists usually explain this behaviour by arguing that girls are only expected to be part of the labour force briefly, before marriage, so that expensive career preparation is not deemed economic. It will be interesting to see whether in the terminal vocational course the percentage of girls was substantially higher than in the pre-university programme, as previous participation patterns would lead us to expect. If girls in the pre-university programme did not then continue on to university it is arguable that they were defining the CEGEP as an extension of secondary school rather than as part of a post-secondary sequence. Alternatively, particularly if a significant proportion of boys also terminated their studies at the end of the pre-university programme, this might indicate that university fees continued to be an important deterrent to studies. Verification would however require further investigation.

On the other hand, female participation in the labour force in Canada has been steadily increasing: in 1971 the female participation rate in the labour force was $36.5 \%$, in contrast with $28.8 \%$ in 1961 . This increase occurred for all age groups except the youngest (14-18) and the oldest (over 65) and was due to an increased participation rate for married women (20.8\% to $33.0 \%$ ). (Labour Canada, no date: Tables 5,9). If these trends continue, a majority of women may expect to work during a substantial part of their adult life. Under such circumstances one might expect to find a greater willingness by girls and by their families to invest in the girls' career preparation, even if this did entail university attendance at both undergraduate and post-graduate levels. Although the proportion of women at university has increased, in 1966 they remained under-represented, particularly in francophone Quebec: $27.7 \%$ of the undergraduate students in French language universities were 
women, while the corresponding figure for the English sector was 34.6\% (Denis and Lipkin, 1972: 126). A high proportion of women graduates from the CEGEP pre-university programme continuing to university, especially if the women were not initially underrepresented in this programme, would suggest a trend towards acceptance of more extensive career preparation for women, although again, further study would be required for verification.

With the data at hand, however, it will be possible to ascertain whether subject choice continued to be sex-linked for these students, with girls being more likely to choose courses leading to such "feminine" occupations as nursing, social work and teaching. We can also see whether any such pattern of sex linking was similar for French and English students.

More generally, the hypothesis that there are ethnic differences in values can be examined, using as an indicator the students' choice of specialisation at CEGEP. The French-Canadian value system has been described as favouring more philosophical and classical studies to the detriment of technology and science, an observation which is supported by a comparison of the development of the French-Catholic and English-Protestant educational systems in Quebec (Government of Quebec, 1963; Rioux and Martin, 1964). On the other hand recent educational developments, including the technological emphasis of the University of Sherbrooke and the decision in organising the CEGEP to incorporate technological, scientific and liberal arts programmes in the same institution suggest that the traditional characterisation of French Canadian values has become outmoded. A comparison of the subject choices of French and English students will provide some evidence on that question.

Finally, with regard to social class there is the question of whether the CEGEP graduates are representative of the Quebec population or whether it has been the children of the middle class and skilled workers who have been the main beneficiaries of the educational reforms, as has been the case in Great Britain (Little and Westergaard, 1964) and the United States (Jencks and Reisman, 1968). Since the CEGEPs draw most of their students from a limited geographical area and since social class composition varies both among regions and among ethnic groups, the comparisons will, as far as possible, be made with the appropriate regional and ethnic subgrouping.

Within the sample of graduates, one would expect, given the lower status occupational outcomes from the vocational programme, that a larger proportion of working class students would be enrolled in it than in the pre-university programme. For students of upper middle class origin (children of professionals and managers of large organizations) a technological occupation would imply some downward mobility, particularly for boys, whereas for a working class student it would represent upward mobility.

Insofar as the social class distribution of the two sexes in the pre-university programme is concerned, this would depend on whether the pre-university programme was being treated by the students as terminal or as an intermediate phase in the educational process. In the latter case, that is, if most of the graduates have continued on to university, it is hypothesised that in comparing the social class distribution for each sex, the proportion of upper-middle class girls will be greater than the proportion of upper-middle class boys. Whereas parents of all social classes have been relatively willing to invest in their sons' education, it has been the upper-middle class parents who have been most willing (and able?) to invest in their daughters' education. Thus, while most female CEGEP graduates are likely to be of uppermiddle class origin, the socio-economic status of the male graduates is likely to be more varied. 


\section{The CEGEPS Studied}

The French language CEGEP studied, Sherbrooke, is located in the major urban centre in the Eastern Townships. It had been formed originally as an amalgamation of a local classical college, normal school and institute of technology, and the initial group of graduates were students who had transferred from one of these programmes to the CEGEP one. The other CEGEP, Dawson, was the first anglophone one to be established. Located in Montreal, it was, unlike Sherbrooke, a completely new institution and from its inception attempted to implement a philosophy of educational innovation.

The original research design also included the study of a francophone CEGEP in Montreal to allow for comparisons between a metropolitan and a less highly urbanised francophone milieu. When it became obvious, at an early stage, that the great variability among the Montreal francophone CEGEPs would severely limit comparisons based on a single institution, this element was abandoned.

\section{Methodology}

Random samples were drawn from the first two graduating classes of Sherbrooke (1969, $1970),(\mathrm{N}=138)$, and of Dawson $(1971,1972),(\mathrm{N}=224)$. The Counselling Department at Sherbrooke had conducted a follow-up study of their graduates, and kindly made the results of the 1970 questionnaire available. Additional information about all the graduates was obtained from their initial applications to the CEGEP. A mailed questionnaire incorporating the same information was sent to the Dawson graduates. The response rate was over $90 \%$ for all groups except the Dawson vocational graduates, whose rate was $85 \%$. The following analysis excludes non-respondents, unless stated explicitly to the contrary.

Unfortunately the samples of graduates from the vocational stream were small. At Sherbrooke the majority of graduates in the vocational courses were completing programmes under the auspices of the Institute of Technology. They were excluded from the analysis since the CEGEP treated them as distinct from students completing programmes under its own auspices, but the distinction became evident too late to allow for compensations in the sample size. At Dawson the first cohort from the vocational programme did not graduate until 1972, since theirs was a three year programme. In order to obtain a reasonable sized sample of them, a larger sampling fraction was used than for the 1972 graduates from the general stream.

\section{Discussion of Results}

Passage through the CEGEP system: As is typical throughout the province (Denis, 1973), for most of the graduates the CEGEP was a step in a continuing educational sequence within their local region. $80 \%$ of the Sherbrooke students came from that area, while over $90 \%$ of the Dawson students were residents of greater Montreal. About $85 \%$ of all the graduates had entered CEGEP immediately after completion of secondary school. Moreover, as Table 1 shows, on completion of CEGEP, most of the pre-university graduates continued their studies immediately, usually at a local university, although for the English students in Montreal this still allowed them a choice among at least three institutions. ${ }^{3}$

${ }^{3}$ For the exceptional ones who considered francophone universities as well, there was a choice among five local institutions. 
In view of the fact that all the English universities were actively recruiting students in 1971 and 1972, it is perhaps surprising that 55\% of the Dawson graduates had applied to more than one institution. The acceptance rates indicated that the students had overestimated the competition they might encourter, if this, rather than leaving open as many options as possible, was the reason for their multiple applications. In contrast, $72 \%$ of the Sherbrooke graduates had applied to only one institution, usually University of Sherbrooke. Most of those making multiple applications were in law, where competition is relatively great (C.A.D.R.E., 1973: Tableau 5A).

Most of those in the general stream who did not go to university had nevertheless been accepted at a university. Of those who had applied to university (see Table 1), only 10\% of each sample were not accepted by all of the institutions to which they had applied. Three quarters of those who were not studying full-time the year after graduating from CEGEP were middle class anglophone students. It seems likely that these students had voluntarily made the choice not to attend university, rather than being constrained by circumstances to do so. They completed CEGEP at a point when strong criticism of university education was being voiced, particularly at the institution they had been attending, criticism relating to both the educational value of the university's approach to learning and to the economic value of a degree. In view of Dawson's own orientation to educational innovation one might expect these students to be in the forefront of any moves away from the traditional pattern of learning. It was in fact students in social sciences and language and literature, the two areas of concentration where most innovation occured at Dawson, who chose not to continue their studies: $25 \%$ of the students in each of these areas opted to do other things. However, that so few did not pursue their studies suggests that the perceived alternatives seemed even less appealing. Thus, at least in these two institutions the pre-university CEGEP programme was being treated by the students as part of an educational sequence rather than as a terminal course. The probability of continuing to university from it approached or surpassed the maximum estimation that Pike had calculated for the high school-touniversity transition (1970: 25-26).

Of those in vocational programmes, virtually all obtained jobs which they considered were related to their professional training in CEGEP. It is likely that the coordinating committee which the Sherbrooke CEGEP had set up to liaise with potential employers in the region (Fournier, 1971) contributed to the graduates' success in obtaining positions there. However, several Dawson graduates volunteered the information that employers did

Table 1

\section{University Applications and Attendance}

Dawson

$90 \%$

$55 \%$

$83 \%$

Entered university immediately after CEGEP
Applied to at least one university

Applied to more than one university
$100 \%$

$72 \%$

$94 \%$ 
not seem to be aware of what students' training had entailed, and a province wide study of 1971-72 graduates (C.A.D.R.E., 1973) found a somewhat lower rate of satisfaction than the Dawson and Sherbrooke students reported. $27 \%$ of the graduates throughout the province felt their job corresponded poorly to their CEGEP specialisation.

Just prior to the graduation of the first CEGEP students in the province concern was expressed by them about availability of university places and jobs. On the one hand it was feared that employers would not appreciate the extent of specialised training which had been part of the vocational course, or that it would prove inappropriate for available jobs: on the other hand, for graduates from the general programme there were the dual concerns about whether sufficient university places would be available, particularly in the French sector, and how universities would view CEGEP qualifications. Insofar as these first graduate from Dawson and Sherbrooke are concerned, the integration of the CEGEP into the existing work and educational structures was good. The results were poorer for the students in the province-wide follow-up study of $1970-71$ graduates (C.A.D.R.E., 1973). As we have noted a larger proportion of the vocational graduates did not feel that their jobs were related to their CEGEP training, while the average proportion of applicants refused admission to the francophone universities ranged from 3\% at the Rimouski and Chicoutimi campuses of the University of Quebec to $24 \%$ at the University of Sherbrooke. The refusal rate varied markedly between faculties in most institutions, with lack of places and poor academic results being the most common reasons given for refusing admission. As the number of CEGEP graduates increases the former reason will undoubtedly become even more important. Unless more places become available in the older universities or the smaller campuses of the University of Quebec become more attractive alternatives, the competition for university places is likely to become a source of strain in the educational system in the near future.

Sex: Some of the most dramatic changes in student composition have occurred in connection with sex inequalities of attendance at post-secondary institutions. At Dawson girls accounted for approximately $50 \%$ of the graduates in each type of programme. At Sherbrooke they also constituted about $50 \%$ of the graduates overall, but this subdivided to approximately $40 \%$ of the pre-university graduates and almost all the careers ones. ${ }^{4}$ Although these are higher than the overall sex ratio for Quebec CEGEPs, the latter still indicated that significantly more young women were at CEGEP than at university (Denis and Lipkin, 1972). Comparisons of the proportion of women at CEGEP and CEGEP-equivalent institutions for the whole of Quebec suggests that the availability of free post-secondary education is an important variable in whether women continue their education beyond secondary school: $44 \%$ of those in CEGEP were women in 1970, including one half of the students who had entered the pre-university programme that year. On the other hand, only $37 \%$ of those in fee-paying CEGEP-equivalent programmes were women (Statistics Canada, 1971 a; Statistics Canada, 1971 b). Since almost all of the CEGEP graduates in the pre-university programmes at Sherbrooke and Dawson continued on to university, it would seem that by that stage fees had become less of a hurdle, perhaps because of the investment already made.

Another notable point was the lack of consistent variation within institution in sex ratio

${ }^{4}$ The latter is due to the specialisations available within the CEGEP at that time, since pure science technology graduates were still completing Institute of Technology courses. 
by social class, rural-urban residence or mother tongue. This indicates either an overall internalization of the values of industrial society which stress the need for widespread continued education, or else that the CEGEP is being defined simply as a continuation of high school. At high school the percentage of girls has typically equalled or exceeded that of boys, with the ratio reversing at university. That most of the young women in the sample entered university upon completing the general programme at CEGEP calls into question the hypethesis that the CEGEP was equated with the high school.

As Tables 2 and 3 show, a dimension on which less change has occurred is that of sex differences in choices of specialisation. Young women still tended to make distinctive and predictable selections, though this phenomenon was more marked among the English students than the French. 38\% of the women at Dawson in general programmes were enrolled in the language and literature specialisation, and an additional $23 \%$ in social sciences. Radiography and social aide courses each accounted for one third of the women in the Dawson vocational programmes. A common career following from languages and literature is teaching, which is a relatively immediate and clear-cut career goal. The same is true of the social aide programme and health science technologies and both these specialties are typically heavily subscribed by women. Lipkin (1971) and Escande (1973) emphasised the same phenomenon in their data: there were a relatively limited range of courses, leading to traditionally "female" occupations, which most girls selected.

On the other hand, the women at Sherbrooke entered a more diverse range of specialities in the general stream, although few chose commerce. As at Dawson, the women in the vocational stream were concentrated in social assistance and laboratory technology courses. Most of the men (but none of the women in the vocational programme) were taking physical science technology courses of the former Institute of Technology, and consequently do not appear in this data.

On the basis of a opinion survey conducted in 1964 among young francophone Quebecers, Rioux and Sevigny (1965) suggested that French Canadian young women were more receptive to change and less bound by tradition than their male counterparts. Our findings here suggest that they may also be less bound by traditional definitions of sex roles than the English women. However, Lipkin, (1971) Baby (Baby et al, 1969) and Escande (1973) all noted a preponderance of "traditional" subject choices by the women in their samples. Those findings, together with Breton's (1972) on high school students, indicate that the relation of sex to occupational aspirations still needs considerable investigation, preferably with controls for such variables as ethnicity and regions of residence.

Language and choice of specialisation: Turning to the association of factors other than sex with choice of specialisation, we should note that the specialities available to English students were of a much more general nature than those available in the French system. The English students chose "social sciences" rather than the "geography," "history" and so forth open to the French students. This is a result of compromises between the two ethnic groups in evolving curriculum details: on the surface the English is a more pragmatic, general system. Although the specialities are differently defined in the two systems, it is possible to group the programmes, so that ethnic patterns of choice can be compared. Here just students in the general programme will be considered, a limitation which only significantly affects the 
Table 2

Sex Distribution by Specialization (General Programme)

for Sherbrooke and Dawson

\begin{tabular}{|c|c|c|c|c|c|c|c|c|c|}
\hline & $\begin{array}{l}\text { Health } \\
\text { Science }\end{array}$ & $\begin{array}{l}\text { Pure \& Applied } \\
\text { Science }\end{array}$ & Law & $\begin{array}{c}\text { Social } \\
\text { Science }\end{array}$ & $\begin{array}{l}\text { Social Service } \\
\& \text { Education }\end{array}$ & Language & Commerce & $\begin{array}{l}\text { Fine } \\
\text { Arts }\end{array}$ & $(\mathrm{N})$ \\
\hline \multicolumn{10}{|l|}{ Sherbrooke } \\
\hline Male $\%$ & 9.5 & 6.3 & 17.5 & 27.0 & 1.6 & 20.6 & 17.5 & - & (63) \\
\hline Female $\%$ & 7.3 & 7.3 & 17.1 & 14.6 & 14.7 & 36.6 & 2.4 & - & (41) \\
\hline \multicolumn{10}{|l|}{ Dawson } \\
\hline Male $\%$ & 6.8 & 29.7 & - & 31.1 & - & 18.9 & 5.4 & 8.1 & (74) \\
\hline Female $\%$ & 5.8 & 10.5 & - & 23.3 & 5.8 & 38.4 & 1.2 & 15.1 & (86) \\
\hline
\end{tabular}

$\begin{array}{ll}\text { Sherbrooke: } & \chi^{2}=15.4, \mathrm{df}=6 . \\ \text { Dawson: } & \chi^{2}=21.9, \mathrm{df}=6 .\end{array}$ 
Tabel 3

Sex Distribution by Specialization (Professional Programme)

for Sherbrooke and Dawson

\begin{tabular}{lcccc}
\hline $\begin{array}{l}\text { Pure Science } \\
\text { Technology }\end{array}$ & $\begin{array}{c}\text { Health Science } \\
\text { Technology }\end{array}$ & $\begin{array}{c}\text { Social Science } \\
\text { Technology }\end{array}$ & $\begin{array}{c}\text { Commerce } \\
\text { Technology }\end{array}$ \\
\hline
\end{tabular}

Sherbrooke

\begin{tabular}{llccc} 
Male $\%$ & - & 60.0 & 40.0 & $(5)$ \\
Female $\%$ & - & 48.3 & 51.7 & $-\quad(29)$ \\
\hline
\end{tabular}

Dawson

\begin{tabular}{lrrrrr} 
Male & $\%$ & 66.7 & 9.5 & - & 23.8 \\
Female $\%$ & 4.8 & 47.6 & 33.3 & 14.3 \\
\hline
\end{tabular}

Sherbrooke: $\quad \chi^{2}=14.1, \mathrm{df}=2$.

Dawson: $\quad \chi^{2}=24.1, \mathrm{df}=3$. 
distribution of French women, as a comparison of Tables 2 and 3 shows. Comparisons of French and English value orientations and of university enrolments would lead us to expect more English students in the pure and applied sciences and commerce and fewer in the humanities. Approximately $15 \%$ of each group selected science for their specialisation, except for the Dawson men, 37\% of whom did so. On the other hand, the proportion in commerce was smaller at Dawson than at Sherbrooke. Moreover a slightly larger proportion of the students at Dawson than at Sherbrooke were in languages and literature. This, like much of our evidence, suggests that the variation in terms of ethnicity was relatively unimportant, and that a common set of values associated with an industrialised society have informed the choices in both ethnic groups.

Social Class Composition: Social class was measured by father's occupation, using the PineoPorter scale of occupations (Pineo and Porter, 1967). Father's occupation, which is the most widely used measure of students' social class,

sums up a series of socio-economic factors which at a very early stage begin to influence the child's educational progress and expectations, and for this reason it is a good predictor of whether or not the child will complete high school and enter university (Pike, 1970: 54).

Even though the CEGEPs are tuition free, as Table 4 indicates, the two studied were largely middle class institutions. Enrolment statistics indicate that it was primarily young men, probably from the upper middle class, who availed themselves of the alternative, feepaying institutions which still existed in each community. Despite this, a larger proportion of the male students at Sherbrooke were from upper-middle class backgrounds, while more of the women had fathers with manual occupations. By and large the pattern of sex differences was reversed at Dawson.

These distributions together with those of the Montreal CEGEPs in Lipkin's (1971) and Escande's (1973) studies, and of the Quebec City CEGEPs which Baby (1969) studied point to the hazards of generalizing about the class composition of the overall CEGEP system from selected institutions. Among the Montreal francophone CEGEPs that Escande studied, for instance, the proportion of upper-middle class students ranged from $19 \%$ to $5 \%$. Comparisons of CEGEPs are further complicated by the variety of scales different investigators have used to classify occupations. Overall, though, in 1969, upper-middle class students made up $35 \%$ of the CEGEP population, and $41 \%$ of the population in the Quebec universities. Complementing this, $38 \%$ of the students in the CEGEPs were of working class origin, in comparison with $25 \%$ in the universities (D.B.S., 1970). ${ }^{5}$ Considering both the individual and province-wide studies to date, the results neither clearly support nor refute the hypothesis that lower-middle class and upper-lower class young people have benefit ted disproportionately from the reforms, as the findings of Little and Westergaard (1964) and Jencks and Riesman (1968) might have led us to expect.

$5_{\text {Special run of data. Upper middle class included professionals, semi-professionals, proprietors and }}$ managers of large enterprises. Working class included skilled, semi-skilled and unskilled workers and farmers. 
Table 4

Social Class ${ }^{1}$ Composition of Sherbrooke and Dawson Graduates

\begin{tabular}{|c|c|c|c|c|c|c|c|c|c|c|c|c|c|}
\hline \multirow{3}{*}{\multicolumn{2}{|c|}{ Nonmanual }} & \multicolumn{6}{|c|}{ Dawson } & \multicolumn{6}{|c|}{ Sherbrooke } \\
\hline & & \multicolumn{2}{|c|}{ General } & \multicolumn{2}{|c|}{ Professional } & \multicolumn{2}{|c|}{ Total } & \multicolumn{2}{|c|}{ General } & \multicolumn{2}{|c|}{ Professional } & \multicolumn{2}{|c|}{ Total } \\
\hline & & $\begin{array}{c}\text { Male } \\
\%\end{array}$ & $\begin{array}{c}\text { Female } \\
\%\end{array}$ & $\begin{array}{c}\text { Male } \\
\%\end{array}$ & $\begin{array}{c}\text { Female } \\
\%\end{array}$ & $\underset{\%}{\text { Male }}$ & $\begin{array}{c}\text { Female } \\
\%\end{array}$ & $\underset{\%}{\text { Male }}$ & $\begin{array}{c}\text { Female } \\
\%\end{array}$ & $\begin{array}{c}\text { Male } \\
\%\end{array}$ & $\begin{array}{c}\text { Female } \\
\%\end{array}$ & $\underset{\%}{\text { Male }}$ & $\underset{\%}{\text { Female }}$ \\
\hline \multirow[t]{2}{*}{ a) } & Upper middle class & & & & & & & & & & & & \\
\hline & $\begin{array}{l}\text { Professional, semi- } \\
\text { professional \& owners } \\
\text { large. }\end{array}$ & 36 & 42 & 19 & 19 & 32 & 37 & 23 & 15 & * & 11 & 24 & 13 \\
\hline \multirow[t]{3}{*}{ b) } & Lower middle class & & & & & & & & & & & & \\
\hline & Owners, small & 19 & 19 & 33 & 33 & 22 & 22 & 31 & 28 & - & 21 & 29 & 25 \\
\hline & Clerical \& Sales & 10 & 7 & 5 & 5 & 8 & 6 & 8 & 13 & - & 11 & 7 & 12 \\
\hline
\end{tabular}

\section{Manual}

$\begin{array}{lrrrrrrrrrrrrr}\text { Skilled } & 14 & 17 & 14 & 24 & 14 & 19 & 6 & 2 & - & -- & 5 & 1 \\ \text { Semi-skilled } & 11 & 7 & 19 & 5 & 13 & 6 & 6 & 8 & - & 11 & 5 & 9 \\ \text { Unskilled } & 10 & 7 & 9 & 14 & 10 & 8 & 11 & 18 & - & 14 & 11 & 17 \\ \text { Farmers } & - & - & - & - & - & - & 8 & 8 & -- & 18 & 7 & 12 \\ \text { Other } & 1 & 1 & - & -- & 1 & 1 & 8 & 8 & * & 14 & 11 & 10 \\ (\mathrm{~N}) & (78) & (95) & (27) & (24) & (94) & (107) & (52) & (39) & (3) & (28) & (55)(67)\end{array}$

1. Defined by Father's occupation which was classified using the Pineo-Porter Scale (1967).

* $\mathrm{N}$ too small to justify percentage computation. 
Apart from the fact that upper-middle class students were significantly more likely to be in the general stream at Dawson, as literature on the United States and Britain would have led us to expect, there were no clearcut social class variations between graduates in different areas of specialisation. The preponderance of working class students in commerce and applied science which had also been a characteristic British and American finding was not evident here. It is possible, however, that the small numbers of students in commerce and science in both CEGEP's may have masked variations by social class.

Table 5 compares the social class composition of the graduates with that of the regions from which they come. With $28 \%$ (mainly francophone) of the area population and $55 \%$ of the graduates in the non-manual category at Sherbrooke, it is obvious that the probability of successfully entering and completing CEGEP was associated with social origin in that predominantly francophone institution. ${ }^{6}$ On the other hand, greater Montreal is more ethnically heterogeneous than any other region in the province, a fact which is reflected in the student body of the anglophone but not the francophone Montreal CEGEPs (Lipkin, 1971 ; Escande, 1973), all of the latter being well over 90\% French. Dawson's graduates, however, included 10\% whose mother tongue was French and 20\% whose first language was neither English nor French. The francophone graduates were overwhelmingly middle class, while the disparities between the graduates whose mother tongue was English and the province's ${ }^{7}$ English population were somewhat less marked: $70 \%$ of the former and $59 \%$ of the latter were of non-manual origin. However for those of "other" mother tongues the social class distributions for the graduates and the Quebec population were very similar, indicating that for this group attending CEGEP was not significantly affected by social class.

It seems likely that cultural factors were operating on at least a couple of dimensions in producing these results. On the one hand is the cultural variation in the importance ascribed to mass education, which has typically been lower among the French, particularly those in rural areas. On the other hand is the variation in the perception of availability of education for self: here it is possible that relative newcomers may not only be more highly motivated towards upward mobility (presumably most came to Canada to improve their position), but also may give greater credence to the ideology which allows for upward mobility by means of educational achievement. If so, they might be very ready to take advantage of the new educational structures. These ethnic differences, however, are something which requires further investigation.

Concluding Remarks: In summary, the findings of the Dawson-Sherbrooke study suggest that the CEGEP is perceived as part of a cycle of post-secondary education, leading on, for most pre-university graduates, to the university. The pattern of university applications of the students, together with the probability of attending a local CEGEP, suggest that the availability of education locally may be of major significance in determining whether or not

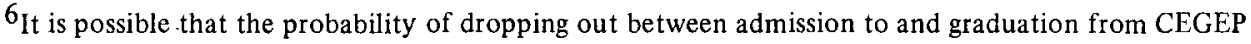
is inversely related to class. Our data did not permit examination of that hypothesis.

${ }^{7}$ The Census does not give a break-down of occupation by mother tongue fór Montreal or the province of Quebec. It only gives occupation by ethnic origin for the province, and not for Montreal alone, but $71 \%$ of the English and $85 \%$ of those of other ethnic origin live in Metropolitan Montreal. 
Table 5

Percentage Distribution of Social Class of CEGEP Graduates and Quebec Labour Force by Ethnicity

\begin{tabular}{|c|c|c|c|c|c|c|c|c|c|c|c|}
\hline & \multicolumn{4}{|c|}{ Quebec Provincel } & \multirow{2}{*}{$\begin{array}{c}\text { Montreal }^{2} \\
\text { Total }\end{array}$} & \multicolumn{4}{|c|}{ Dawson Graduates ${ }^{3}$} & \multirow{2}{*}{$\begin{array}{c}\text { Eastern } \\
\text { Townships }^{4} \\
\text { Total }\end{array}$} & \multirow{2}{*}{$\begin{array}{c}\text { Sherbrooke } \\
\text { Graduates }{ }^{5,3} \\
\text { Total }\end{array}$} \\
\hline & Total & French & English & Other & & Total & French & English & Other & & \\
\hline Nonmanual & 31 & 27 & 50 & 40 & 59 & 64 & 75 & 70 & 40 & 28 & 55 \\
\hline Manual & 69 & 73 & 50 & 60 & 41 & 36 & 25 & 30 & 60 & 72 & 45 \\
\hline
\end{tabular}

1. Census of Canada, 1961. The Census does not give a breakdown of occupation by Ethnicity for Montreal, but 71 percent of the English and 85 percent of those of other ethnic origins live in Metropolitan Montreal.

2. J. Lipkin, "The Selection and Allocation of Students in two Montreal CEGEPs." No breakdown of occupation by ethnicity is published for Montreal, but the bulk of non-French Quebecers live there.

3. Ethnicity was determined by student's mother tongue, and social class by the occupation of the graduate's father.

4. Census of Canada, 1961, for the three counties from which 79 percent of the Sherbrooke students came. This area is over 80 percent French.

5. Over 95 percent of the graduates are French. 
students pursue their studies to the post-secondary level. The raw data from the C.A.D.R.E. study (1973) would allow us to test this hypothesis that a smaller proportion of CEGEP graduates from areas with no local university do in fact attend university. Unfortunately the data have not been published in such a way that the hypothesis can be tested at the moment.

Women constituted a significant proportion of the graduates in both streams, and the fact that most pre-university graduates entered university suggests increasing acceptance of relatively long-term career goals for women. On the other hand, a strong association between sex and choice of specialisation remained.

Subsequent access to university or suitable employment does not seem to have been a problem for these graduates, though the C.A.D.R.E. results suggest that with the rapid increase in CEGEP enrolments, this situation is deteriorating.

Social classes continued to be inequitably represented in the student population, and children of working class origin were somewhat more likely to be enrolled in the careers programme. There were neither clearcut patterns of ethnic differences in the students' choice of subject or subsequent career decisions, nor, within each stream, were there consistent social class differences. This reflects, perhaps, the necessity of internalizing middle class "Anglo-Saxon" norms if one is to succeed in the educational system. From this it seems that sex is a more significant determinant of variation at the CEGEP level than ethnicity or social class. However, because of its limited nature this study can only be suggestive in its conclusions and we must hope for a more extensive study of the CEGEP in the near future. 


\section{References}

Baby, A., P. Bélanger, R. Ouellet, "Nouveaux aspects du problème de la démocratisation de l'enseignement collégial," L'Orientation Professionnelle. 5.2. (1969).

Breton, Raymond, Social and Academic Factors in the Career Decisions of Canadian Youth, Ottawa: Department of Manpower and Immigration, 1972

Centre d'animation, de développement et de recherche en éducation, Annuaires 1971.72 CEGEP$A C Q$. Montréal: C.A.D.R.E., 1972.

Centre d'animation, de développement et de recherche en éducation, Rapport statistique sur les sortants de l'enseignement collégial en 1970-71. Montréal: C.A.D.R.E., 1973.

CEGEP de Sherbrooke, Follow-up, Sherbrooke: Service d'Orientation, CEGEP de Sherbrooke, 1971.

Denis, A., "Patterns of CEGEP Attendance," Paper presented at the Annual Meeting, Canadian Society for the Study of Higher Education, Kingston, Ontario, 1973.

Denis, A., "CEGEP Students: Varieties in Socialization Experience" in R. Pike and E. Zurick, Socialization and Social Values in Canada, Toronto: New Press, in press.

Denis, A., J. Lipkin, "Quebec's CEGEPS: Promise and Reality." McGill Journal of Education, 72:119-34

Dominion Bureau of Statistics, Post Secondary Student Population Survey 1969, Ottawa: Queen's Printer, 1970.

Escande, C., Les classes sociales au CEGEP, Montréal: Parti Pris, 1973.

Fournier, J., Ebauche: Communication sur le CEGEP du Québec au Canada," unpublished paper, 1971.

Frère, Untel, Les Insolences du Frère Untel, Montréal: Les Editions de l'Homme, 1960.

Gouvernement du Québec, Défi et Dilemmes, Québec: Editeur Officiel, 1972.

Government of Quebec, Royal Commission of Inquiry on Education in the Province of Quebec, Report. Vol. 1, Quebec: Government of Quebec, 1963. (The Parent Report).

Guindon, H., "Social Unrest, Social Class and Quebec's Bureaucratic Revolution," Queens Quarterly, LXXI (Summer, 1964) pp. 150-162.

Hall, D., "The Canadian Division of Labour Revisited", in R. J. Ossenberg, Canadian Society: Pluralism, Change and Conflict, Scarborough, Ontario: Prentice - Hall Canada, 1971

Halsey, A. H., Jean Floud, C. A. Anderson, Education, Economy and Society, New York: Free Press, 1961.

Jencks, C., D. Riesman, The Academic Revolution, New York: Doubleday, 1968.

Joy, R., Languages in Conflict, Toronto: McClelland and Stewart, 1972.

Labour Canada, Women in the Labour Force 1971, Ottawa: Women's Bureau, Labour Canada, n.d.

Lipkin, J., "Selection and Allocation of Students in Two Montreal CEGEPs," Paper presented at Canadian Educational Researchers Association Annual Conference, Memorial University, Newfoundland, 1971.

Little, A., J. Westergaard, "Trend of Class Differentials in Educational Opportunity in England and Wales," British Journal of Sociology 15 (December 1964).

Organization for Economic Cooperation and Development, Development of Secondary Education, Paris: Unesco, 1969.

Ouellet, R., A. Baby, P. Bélanger, "Les Orientations des Etudiants du cours collégial in Gouvernement du Québec," éd., Défi et Dilemmes, pp. 51-112. Québec: Editeur Officiel, 1972.

Pike, R., Who Doesn't Get to University. . And Why, Ottawa: A.U.C.C., 1970.

Pineo, P., J. Porter, "Occupational Prestige in Canada," Canadian Review of Sociology and Anthropology, 4, 1(February 1967), pp. 24-40.

Porter, J., The Vertical Mosaic, Toronto: University of Toronto Press, 1965.

Rioux, M., Y. Martin, French Canadian Society, Toronto: McClelland and Stewart, 1964.

Rioux, M., R. Sevigny, Les nouveaux citoyens, Montreal: Service des Publications Radio-Canada, 1965.

Sewell, W., “Opportunity for Education," American Sociological Review, 36 (October 1971), pp. 793-809. 
56 Ann B. Denis

Statistics Canada, Canadian Community Colleges and Related Institutions, 1970-71, Cat. 81-222.

Ottawa: Queen's Printer, 1971a.

Statistics Canada, Fall Enrolment in Universities and Colleges, 1970-71, Cat. 81-204. Ot tawa: Queen's Printer, $1971 \mathrm{~b}$. 